\title{
FORMULASI SABUN CAIR WANITA EKSTRAK ETANOL DAUN KEMANGI (Ocimum sanctum L) DAN AKTIVITASNYA TERHADAP Candida albicans
}

\author{
WOMEN'S LIQUID SOAP FORMULATION ETHANOL EKSTRACT \\ OF KEMANGI LEAVES (Ocimum sanctum L) AND THE ACTIVITY \\ AGAINST Candida albicans
}

\author{
Trilestari, Ismiyati, Deddy Groho Suwardjo \\ Poltekkes Bhakti Setya Indonesia Yogyakarta \\ Email: tri.lestari81@ rocketmail.com
}

\begin{abstract}
ABSTRAK
Infeksi candida terjadi pada sebagian besar wanita. Jamur ini merupakan flora normal tubuh. Namun pada saat kondisi tubuh menurun infeksi candida menjadi sangat berbahaya. Tujuan penelitian ini adalah untuk mengetahui adanya aktivitas anti jamur dari ekstrak etanol daun kemangi (Ocimum sanctum L) terhadap Candida albicans dan memformulasinya menjadi sediaan sabun cair untuk wanita. Penelitian ini menggunakan metode rancangan posttest only control groups. Penelitian dilakukan dengan cara remaserasi daun kemangi menggunakan etanol 96\%. Ekstrak etanol daun kemangi (EEK) dengan konsentrasi 5\%, 10\%, 20\%, 40\%, 60\% diuji aktivitasnya sebagai anti candida. Kontrol negatif digunakan DMSO dan kontrol positif nystatin 100 UI. Kemudian dibuat sabun cair dengan konsentrasi 1\%, 5\%, $10 \%$. Aktivitas anti candidanya diuji dengan menggunakan kontrol negatif basis krim dan kontrol positif sabun cair lactacid. Uji aktivitas anti candida menggunakan metode difusi padat. Aktivitas anti candida EEK dan sabun cair EEK dinyatakan dengan diameter zona hambat. Hasil yang diperoleh yaitu EEK dengan kadar 10\%, 20\%, 40\%, dan 60\% sensitif terhadap Candida albicans. Sediaan sabun cair wanita yang mengandung EEK dalam kadar 1\%, 5\%, dan $10 \%$ memiliki aktivitas anti jamur dalam menghambat pertumbuhan Candida albicans. Berdasarkan penelitian yang telah dilakukan maka dapat disimpulkan bahwa sabun cair EEK kadar 1\%, 5\%, dan 10\% potensial sebagai anti jamur terhadap Candida albicans.
\end{abstract}

Kata kunci : ekstrak etanol daun kemangi, sabun cair, anti-candida

\section{ABSTRACT}

Candida infection occurs in most women. Mold is a normal flora of the body. However, when the condition of the body decreases candida infection becomes very dangerous. The purpose of the study is to determine the anti-fungal activity of the 
ethanol extract of kemangi leaves (Ocimum sanctum L) against Candida albicans and formulating them into a liquid soap for women. Method of the study design was posttest only control groups. Research conducted by remaseration of kemangi leaves using ethanol $96 \%$. The ethanol extract of kemangi leaves (EEK) with concentration $5 \%, 10 \%, 20 \%, 40 \%, 60 \%$ tested its activity as anti-candida. Negative control was DMSO and positive control used nystatin 100 IU. Then made liquid soap with concentration of 1\%, 5\%, 10\%. The activities against Candida albicans tested using negative control (cream base) and positive control (lactacid). Anti-candida activity tested using solid diffusion method. Anti-candida activity of EEK and liquid soap of EEK expressed with diameter of inhibition zone. Results is EEK with levels of 10\%, 20\%, 40\%, and 60\% sensitive to Candida albicans. Preparations of liquid soap woman containing EEK levels of 1\%, 5\%, and 10\% have anti-fungal activity in inhibiting the growth of Candida albicans. Conclusion is liquid soap of EEK levels of $1 \%, 5 \%$, and $10 \%$ has potential as antifungal agains Candida albicans.

Keywords: ethanol extract of kemangi leaves, liquid soaps, anti-candida

\section{PENDAHULUAN}

Iklim tropis dengan kelembaban udara tinggi di Indonesia ditambah lingkungan yang padat dan sosio ekonomi yang rendah serta higiene dan sanitasi lingkungan kurang membuat infeksi jamur mudah terjadi. Salah satu infeksi fungi yang terjadi yaitu infeksi oleh Candida albicans atau biasa disebut kandidiasis (Pratiwi, 2008).

Candida albicans dalam keadaan normal merupakan flora normal, dimana Candida albicans berada dalam keadaan seimbang dengan flora bakteri. Candida albicans dapat menjadi pathogen, bila terdapat situasi yang memungkinkan untuk terjadinya multiplikasi. Penyakit yang disebabkan oleh Candida albicans diantaranya sariawan, nyeri perut dan keputihan. Adapun situasi yang memicu infeksi ini antara lain kebersihan yang kurang, penyakit diabetes dan stres.

Jika dibandingkan dengan jumlah obat anti bakteri obat anti jamur relatif lebih sedikit. Seiring berkembangnya penyakit HIV, beberapa obat anti jamur dapat mengalami resistensi. Disisi lain pengobatan barat diliputi semangat back to nature, yaitu pemanfaatan obat-obat alternatif dengan menggunakan tanaman tradisional semakin sering dilakukan. Hal ini dilakukan agar diperoleh agen anti fungi yang lebih aman, tidak resisten, dengan sedikit efek samping (Sapoetra, 2004). 
Indonesia kaya akan sumber bahan alam dan obat tradisional yang digunakan sebagian rakyat Indonesia secara turun temurun. Namun demikian masih banyak tanaman di Indonesia yang mengandung bahan obat yang belum diteliti lebih lanjut dan diolah menjadi sediaan obat yang berguna, baik untuk tujuan kemanusiaan maupun tujuan komersil. Salah satu tanaman tradisional yang diduga memiliki senyawa yang berpotensi sebagai anti jamur adalah daun kemangi (Tjay dan Rahardja, 2007).

Daun kemangi mengandung flavonoid, alkaloid, saponin, tannin dan triterpenoid yang berpotensi sebagai anti fungi, oleh karena itu tujuan penelitian ini adalah untuk mengetahui adanya aktivitas anti jamur dari EEK terhadap Candida albicans dan memformulasinya menjadi sediaan sabun cair untuk wanita.

\section{METODE PENELITIAN}

Alat yang digunakan dalam penelitian ini adalah seperangkat alat maserasi dan uji mikrobiologi. Bahan yang digunakan berupa daun kemangi segar diperoleh dari daerah Wonosari, Gunungkidul Yogyakarta, Candida albicans yang diperoleh dari Laboratorium Mikrobiologi Politeknik Kesehatan Indonesia Yogyakarta, PDA (Potato Dextrose Agar), $\mathrm{NaCl}$ (Natrium Clorida), akuades, Nystatin drop (PT. Mestika Farma), Lactacyd ${ }^{\circledR}$ (PT. Pharma Health Care), alkohol 96\%, Na lauril sulfat, Setil alkohol, Cera alba, Adeps lanae, Propilen glikol, Asam sitrat, dan akuades. Jalannya Penelitian

1. Pembuatan ekstrak kental

Sebanyak $250 \mathrm{~g}$ simplisia kemangi dimaserasi dengan pelarut etanol 96\% sebanyak 7,5 kali bobotnya selama 5 hari. Dipisahkan sari dari ampas dengan menggunakan kain saring, pada ampas diremaserasi dengan etanol 96\% sebanyak 2,5 kali bobot simplisia, diamkan selama 2 hari, setelah itu disaring. Ekstrak cair yang sudah diperoleh kemudian diuapkan untuk mendapatkan ekstrak kental. 
2. Uji aktivitas anti candida EEK

Dibuat larutan EEK dalam DMSO dengan konsentrasi 5\%, 10\%, 20\%, 40\%, $60 \%$. Sebanyak masing-masing $30 \mu 1$ larutan EEK diletakkan dalam sumuran pada media PDA yang sudah ditanami Candida albicans. Kontrol positif digunakan Nystatin (100 IU) dan kontrol negatif digunakan DMSO. Diinkubasi selama 24 jam pada inkubator dengan suhu $37^{\circ} \mathrm{C}$.

3. Formulasi Sediaan Sabun

Sediaan sabun cair wanita EEK dibuat dengan formula seperti pada Tabel I.

Tabel I. Formula sabun cair wanita

\begin{tabular}{lr}
\hline \multicolumn{1}{c}{ Bahan } & Jumlah \\
\hline Na Lauril Sulfat & $10 \mathrm{~g}$ \\
Propilen glikol & $4 \mathrm{~g}$ \\
Setil alkohol & $2 \mathrm{~g}$ \\
Adeps Lanae & $2 \mathrm{~g}$ \\
Cera flava & $2 \mathrm{~g}$ \\
Asam sitrat & $0,25 \mathrm{~g}$ \\
Akuades & Hingga $100 \mathrm{~mL}$ \\
\hline
\end{tabular}

a. Bahan-bahan fase minyak (adeps lanae, cera flava, setil alkohol) dan fase air (natrium lauril sulfat, propolenglikol dan sebagian akuades) dilelehkan pada wadah terpisah di atas waterbath sampai lebur pada suhu $70^{\circ} \mathrm{C}$.

b. Fase minyak dimasukkan ke dalam mortir panas yang sudah dikeringkan, kemudian fase air dituang sedikit demi sedikit sambil diaduk cepat sampai terbentuk emulsi, kemudian ditambahkan air sedikit demi sedikit sampai $100 \mathrm{~mL}$.

c. Pembuatan konsentrasi $1 \%$ sabun cair dilakukan dengan cara menimbang sebanyak 1 g ekstrak, kemudian ditambahkan DMSO 1 mL, kemudian ditambahkan sediaan sabun hingga $100 \mathrm{~mL}$ diaduk sampai homogen.

d. Terakhir ditambahkan larutan asam sitrat sampai $\mathrm{pH}$ 3,5. Dilakukan hal yang sama untuk pembuatan sabun dengan konsentrasi 5\% dan $10 \%$. 
4. Uji daya aktivitas antijamur sediaan sabun cair EEK

Sabun EEK konsentrasi 1\%, 5\%, 10\%, sebanyak $30 \mu 1$ ditanam pada sumuran media PDA yang mengandung Candida albicans. Kontrol positif digunakan lactacid dan kontrol negatif digunakan basis sabun. Diinkubasi selama 24 jam pada inkubator dengan suhu $37^{\circ} \mathrm{C}$.

Analisis Data

Data yang diperoleh berupa zona hambat pertumbuhan Candida albicans dan dianalisis dengan program SPSS .

\section{HASIL DAN PEMBAHASAN}

\section{A. Determinasi Tanaman Kemangi}

Determinasi tanaman kemangi dilakukan di Laboratorium Taksonomi Tumbuhan Fakultas Biologi Universitas Gadjah Mada Yogyakarta. Tanaman kemangi dideterminasi untuk mendapatkan kepastian bahwa tanaman yang digunakan untuk penelitian berasal dari tumbuhan yang dimaksud.

\section{B. Pembuatan EEK}

EEK di buat dengan metode remaserasi dengan alkohol 96\%. Seluruh serbuk simplisia dimaserasi dengan cairan penyari pertama dan dibiarkan selama lima hari, setelah lima hari dilakukan penyaringan dan ampas diperas, ampas tersebut dimaserasi lagi dengan cairan penyari kedua (Depkes RI, 1986).

Tabel II. Hasil remaserasi daun kemangi

\begin{tabular}{cc}
\hline Keterangan & Perhitungan \\
\hline Berat daun basah & $3000 \mathrm{~g}$ \\
Berat simplisia kering & $250 \mathrm{~g}$ \\
Ekstrak kental & $19,25 \mathrm{~g}$ \\
Randemen ekstrak & $7,7 \%$ \\
Kadar air (LOD) & $91 \%$ \\
\hline
\end{tabular}

Keterangan: Randemen ekstrak dihitung dengan cara ekstrak yang didapat dibagi dengan berat simplisia awal dikalikan 100\%. Kadar air (LOD): dihitung dengan cara berat daun basah dikurangi berat simplisia kering dibagi berat daun basah. 
Dipilih metode remaserasi karena pengerjaan dan peralatan yang digunakan sederhana dan mudah didapat, dengan memodifikasi metode maserasi maka zat aktif yang diperoleh juga lebih banyak. Hasil ekstraksi daun kemangi dengan metode remaserasi dapat dilihat pada Tabel II dan Tabel III.

Tabel III. Hasil pengamatan organoleptis ekstrak etanol daun kemangi

\begin{tabular}{cc}
\hline Pengamatan & Keterangan \\
\hline Bentuk & Kental dan pekat \\
Warna & Hitam \\
Bau & Bau khas \\
Homogenitas & Tidak pecah \\
\hline
\end{tabular}

C. Hasil Pengujian Antijamur EEK Berbagai Konsentrasi terhadap Pertumbuhan Candida albicans

Dalam dalam penelitian ini digunakan nystatin sebagai kontrol positif dan DMSO sebagai kontrol negatif. Kontrol positif berfungsi untuk membandingkan daya hambat dari kelompok perlakuan (sampel) dengan obat kimia yang sering digunakan sebagai anti jamur, sedangkan kontrol negatif digunakan untuk mengetahui apakah pelarut yang digunakan dapat mempengaruhi hasil uji anti jamur atau tidak. Hasil pengamatan zona hambat EEK dalam berbagai konsentrasi terdapat pada Tabel IV.

Berdasarkan hasil pengujian didapat konsentrasi EEK yang memiliki aktivitas dalam menghambat pertumbuhan jamur Candida albicans tertinggi adalah pada konsentrasi 60\%. Namun jika dibandingkan dengan kontrol positif (nystatin 100 IU) EEK konsentrasi 60\% aktivitas dalam menghambat pertumbuhan Candida albicans masih lebih rendah dimana diameter zona hambat pada kelompok perlakuan kontrol positif sebesar 18,63 mm. Hal ini dikarenakan dalam EEK terdapat berbagai macam senyawa yang bisa saja mempengaruhi atau menyebabkan berkurangnya aktivitas dalam menghambat pertumbuhan Candida albicans. 
Tabel IV. Hasil pengukuran diameter zona hambat EEK

terhadap pertumbuhan Candida albicans dengan masa inkubasi 24 jam

\begin{tabular}{lccclc}
\hline \multirow{2}{*}{ Perlakuan } & \multicolumn{3}{c}{ Diameter zona hambatan $(\mathbf{m m})$} & \multirow{2}{*}{ Rata-rata } & \multirow{2}{*}{ Keterangan } \\
\cline { 2 - 4 } & $\mathbf{R 1}$ & $\mathbf{R 2}$ & $\mathbf{R 3}$ & & \\
\hline Kontrol (+) & 19,7 & 17,5 & 18,1 & 18,63 & Sensitif \\
Kontrol (-) & 9 & 9 & 9 & 9 & Resisten \\
Konsentrasi 5\% & 12,2 & 11,9 & 11,5 & 11,86 & Resisten \\
Konsentrasi 10\% & 13,0 & 12,8 & 13,1 & 12,96 & Sensitif \\
Konsentrasi 20\% & 13,8 & 13,5 & 13,7 & 13,66 & Sensitif \\
Konsentrasi 40\% & 14,2 & 13,9 & 14,1 & 14,06 & Sensitif \\
Konsentrasi 60\% & 16,1 & 15,9 & 16,3 & 16,1 & Sensitif \\
\hline
\end{tabular}

Keterangan : diameter zona hambatan termasuk diameter sumuran $9 \mathrm{~mm}$

Kontrol positif (nystatin $100 \mathrm{IU}$ ) memiliki zona hambat yang paling tinggi dari kelompok uji yang lain. Hal ini dikarenakan nystatin merupakan obat yang sudah terbukti untuk infeksi Candida albicans. Nystatin hanya akan diikat oleh jamur atau ragi yang sensitif. Aktivitas antijamur tergantung dari adanya ikatan dengan sterol pada membran sel jamur atau ragi terutama sekali ergosterol. Karena mekanisme kerja nystatin adalah dengan jalan berikatan dengan sterol membrane sel jamur, terutama ergosterol. Akibatnya terjadi gangguan pada permeabilitas membran sel jamur dan mekanisme transpornya, akibatnya sel jamur kehilangan banyak kation dan makromolekul (Ganiswara, 1995).

Berdasarkan standar umum yang dikeluarkan Depkes RI (1988) disebutkan bahwa mikroba dikatakan peka/sensitif terhadap antimikroba apabila mempunyai ukuran diameter zona hambat sebesar 12-24 mm. Rata-rata zona hambat EEK konsentrasi 10\%, 20\%, 40\% dan 60\% pada penelitian ini berkisar mulai dari 12-16 mm, hal ini membuktikan bahwa EEK sensitif terhadap Candida dan dapat digunakan sebagai anti jamur terhadap Candida albicans.

Analisis statistik menunjukkan tidak ada perbedaan zona hambat kontrol positif dengan konsentrasi ekstrak 5\%, 10\%, 20\%, 40\%, dan 60\%. Artinya, pada konsentrasi 
terkecil (5\%) memberikan zona hambat yang sama dengan kontrol positif. Hasil pengukuran diameter zona hambat EEK terhadap pertumbuhan Candida albicans dapat dilihat pada Gambar 1.

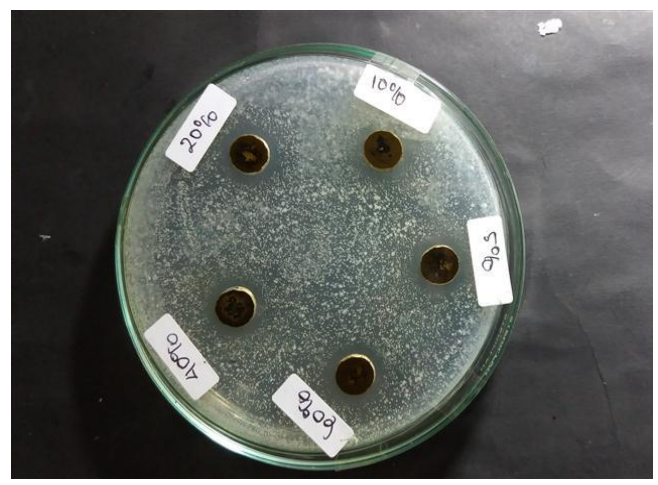

Gambar 1. Zona hambat ekstrak etanol daun kemangi

Daun kemangi mengandung alkaloid, flavonoid, saponin, dan tanin. Flavonoid, tanin dan saponin merupakan senyawa yang mempunyai efek farmakologi sebagai antijamur. Dimana flavonoid dengan kemampuannya membentuk kompleks dengan protein dan merusak membran sel dengan cara mendenaturasi ikatan protein pada membran sel, sehingga membran sel menjadi lisis dan senyawa tersebut menembus ke dalam inti sel menyebabkan jamur tidak berkembang (Sulistyawati dkk., 2009).

Penelitian Puspawati (2007) mengatakan bahwa esktrak soxhletasi daun Centella asiatica dapat menghambat pertumbuhan Candida albicans dengan diameter zona hambat paling tinggi yaitu $18,98 \mathrm{~mm}$, daya hambat ini disebabkan karena dimana senyawa flavonoid, saponin, alkaloid, polifenol yang terkandung dalam esktrak soxhletasi daun Centella asiatica.

Selain itu penelitian Pangalinan dkk. (2013) mengatakan bahwa esktrak etanol batang rambutan dapat menghambat pertumbuhan jamur Candida albicans dengan kandungan senyawa kimia yang terdapat didalam esktrak etanol kulit batang rambutan adalah flavonoid, alkaloid, saponin, tannin dan triterpenoid. Daun kemangi 
mengandung flavonoid, alkaloid, saponin, tannin dan triterpenoid sehingga EEK dapat menghambat pertumbuhan Candida albicans.

D. Hasil Pengujian Daya Hambat Sabun Cair EEK

Dalam penelitian ini digunakan lactacyd ${ }^{\circledR}$ sebagai kontrol positif, formula basis (tanpa ekstrak) sebagai kontrol negatif, dan perlakuan sabun cair EEK dengan konsentrasi 1\%, 5\%, dan 10\%. Hasil diameter zona hambatan dapat dilihat pada Tabel V.

Tabel V. Diameter zona hambat sabun cair EEK terhadap pertumbuhan Candida albicans

\begin{tabular}{lccccc}
\hline \multirow{2}{*}{ Perlakuan } & \multicolumn{3}{c}{ Diameter zona hambatan $(\mathbf{m m})$} & \multirow{2}{*}{ Rata-rata } & \multirow{2}{*}{ Keterangan } \\
\cline { 2 - 4 } & $\mathbf{R 1}$ & $\mathbf{R 2}$ & $\mathbf{R 3}$ & & \\
\hline Kontrol (+) & 22,5 & 22,2 & 22,4 & 22,36 & Sensitif \\
Kontrol (-) & 19,4 & 17,9 & 18,2 & 18,50 & Sensitif \\
Konsentrasi 1\% & 21,0 & 21,5 & 21,3 & 21,26 & Sensitif \\
Konsentrasi 5\% & 22,5 & 22,2 & 22,1 & 22,27 & Sensitif \\
Konsentrasi 10\% & 23,9 & 23,7 & 23,4 & 23,67 & Sensitif \\
\hline
\end{tabular}

Keterangan : diameter zona hambatan termasuk diameter sumuran $9 \mathrm{~mm}$

Berdasarkan hasil pengujian menunjukan bahwa sabun cair EEK memiliki daya hambat terhadap pertumbuhan jamur Candida albicans. Dari hasil pengujian didapat konsentrasi EEK yang memiliki aktivitas paling tinggi dalam menghambat pertumbuhan Candida albicans adalah 10\% dengan zona hambat sebesar 23,67 mm melebihi zona hambat dari kontrol positif. Hal ini disebabkan karena basis sabun cair saja sudah memberikan daya hambat sebesar 18,5 mm, sehingga seiring ditambahnya konsentrasi EEK pada sabun zona hambat akan semakin besar. Sedangkan pada sabun cair EEK konsentrasi 5\% zona hambatnya hampir sama dengan kontrol positif hanya berbeda $0,09 \mathrm{~mm}$ dan sabun cair EEK konsentrasi $1 \%$ zona hambatnya paling kecil. Hasil pengukuran diameter zona hambat sabun cair EEK terhadap Pertumbuhan Candida albicans dapat dilihat pada Gambar 2. 


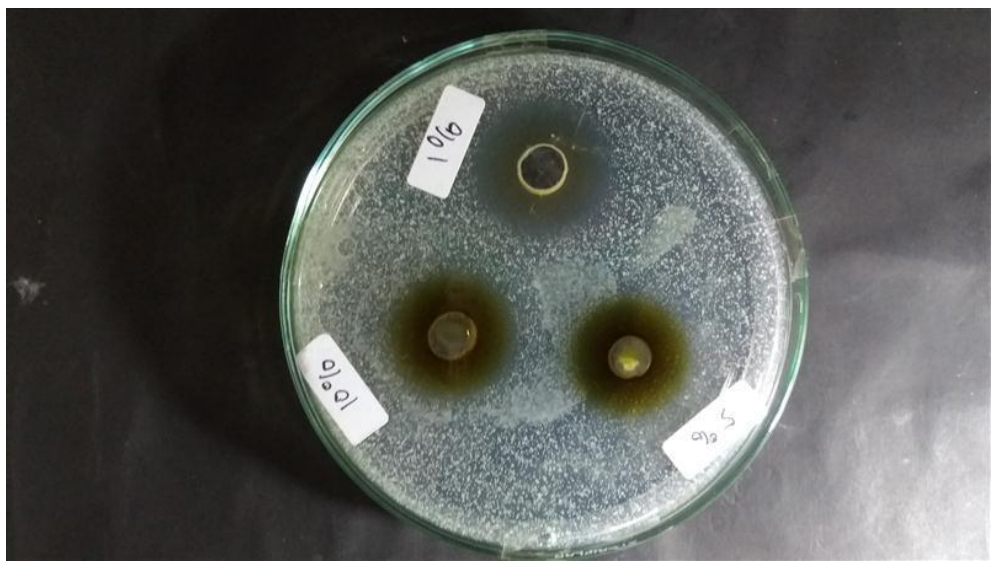

Gambar 2. Zona hambat sabun cair ekstrak etanol daun kemangi

Hasil uji statistik menunjukkan tidak terdapat perbedaan yang bermakna antara kontrol positif dan sabun EEK dalam berbagai konsentrasi dalam menghambat pertumbuhan Candida albicans. Dari hasil penelitian ini menunjukkan bahwa sabun cair EEK dapat menghambat pertumbuhan Candida albicans.

\section{KESIMPULAN}

EEK dengan kadar 10\%, 20\%, 40\%,dan 60\% sensitif terhadap Candida albicans. Sediaan sabun cair wanita yang mengandung EEK dalam kadar 1\%, 5\%, dan $10 \%$ memiliki aktivitas anti jamur dalam menghambat pertumbuhan Candida albicans. sabun cair EEK kadar 1\%, 5\%, dan 10\% potensial sebagai anti jamur terhadap Candida albicans.

\section{UCAPAN TERIMA KASIH}

Penulis mengucapkan terima kasih sebesar-besarnya kepada Kemenristek Dikti yang telah membiayai penelitian ini melalui Hibah Dosen Pemula.

\section{DAFTAR PUSTAKA}

Depkes RI., 1986, Sediaan Galenik, Direktorat Jenderal Pengawasan Obat dan Makanan, Departemen Kesehatan Republik Indonesia, Jakarta. 
Ganiswara, G.S., 1995, Farmakologi dan Terapi, Gaya Baru, Jakarta.

Sapoetra, K., 2004, Pengertian Sel, http://www.biologycell.com/Kartosapoetra, diakses 29 Juli 2016, jam 21.00.

Panglinan, R.F., Kojong, N., dan Paulina V.Y., 2012, Uji Aktivitas Antijamur Ekstrak Etanol Kulit Batang Rambutan (Nephelium lappaceum L.) terhadap Jamur Candida albicans Secara In Vitro, e-Jurnal FMIPA UNSRAT, Manado.

Pratiwi, Slyvia T., 2008, Mikrobiologi Farmasi, Jakarta, Erlangga.

Puspawati, N., 2007, Uji Aktivitas Antijamur Ekstrak Soxhletasi Daun Kaki Kuda (Centella Asiatica, Urb.) terhadap Candida Albicans Atcc 10231 dan Candida Albicans Hasil Isolasi Penderita Sariawan, e-Jurnal Fakultas Biologi, Universitas Setia Budi, Surakarta.

Sulistyawati, D. dan Mulyati, S., 2009, Uji Aktivitas Antijamur Infusa Daun Jambu Mete (Anacardium ocidentale L.) terhadap Candida albicans, Jp Kesmas.

Tjay, H.T. dan Rahardja K., 2007, Obat-obat Penting, Edisi VI, Flex Media Komputindo, Jakarta. 